\title{
Comparing alternative methods of introducing virgin queens (Apis mellifera) into mating nucleus hives*
}

\author{
Juan Antonio PÉREZ-SATo, Francis L.W. RATNIEKS \\ Laboratory of Apiculture and Social Insects, Department of Animal and Plant Sciences, University of Sheffield, \\ Sheffield, S10 2TN, UK
}

Received 17 May 2005 - Revised 19 December 2005 - Accepted 28 December 2005

\begin{abstract}
Three methods of introducing virgin queens into mating hives were compared with the standard method of using a "ripe" queen cell. Virgins were introduced into queenless mating nucleus hives (5-frame medium Langstroth) using a wooden mailing cage with candy and attendant bees and were released three days later. When the caged virgins were $0-1$ days old when introduced, the proportion giving rise to an egg-laying queen $(65 \%)$ was almost as high as with cells $(70 \%)\left(P=0.63, \chi^{2}\right.$ test). Success dropped to $55 \%(P=0.04)$ for 3-4 day old virgins. If the virgin was introduced into a queenright mating hive for three additional days before the colony queen was removed the success rate was only $29 \%(P=0.001)$. Across all methods, most queen loss occurred in the introduction/emergence period, with only one third in the mating period. The time taken to start egg laying, which averaged 12.9 days from emergence, did not vary significantly among methods.
\end{abstract}

Apis mellifera / virgin queen / queen acceptance / queen introduction / queen rearing / queen cell / mating success

\section{INTRODUCTION}

Beekeepers frequently require mated queens to start new hives and replace dead or failing queens. The production of mated queens is an important part of commercial beekeeping (Ruttner, 1983; Laidlaw and Page, 1997). Most commercial queen rearing uses the Doolittle method (grafting of young larvae) to produce queen pupae from worker larvae (Laidlaw, 1993). A queen pupa in her cell is then used to requeen a queenless hive, with the queen mating and commencing egg laying soon after emerging from her cell. An alternative but seldom used method is to allow virgin queens to emerge from their cells in an incubator or in cages within a hive. Caged virgin queens can then be introduced individually into queenless hives (Snelgrove, 1940; review in McCutcheon, 2001).

Corresponding author: J.A. Pérez-Sato, bop02pj@sheffield.ac.uk

* Manuscript editor: Gudrun Koeniger
Although the introduction of virgin queens into mating hives is considered less successful than the use of queen cells (Snelgrove, 1940; Laidlaw, 1979), it has several potential advantages. First, queens can be marked with paint or numbered tags before being introduced, making them easier to find (Laidlaw and Page, 1997). This is especially useful when workers and queens are similar in colour, as in the black honey bee of Britain and NW Europe Apis mellifera mellifera. Second, queens can be selected for desirable physical characteristics (colour, lack of deformities, adequate body size, etc.). In addition, queens can be genotyped, such as by extracting DNA from a minute piece of wing tip (Châline et al., 2004). This may be useful if the queens are part of a breeding program in which genetic markers are used to guide selection prior to mating. Finally, queen rearing productivity may be increased. Queen cells are normally introduced 2 days before the queen emerges. If a virgin queen is introduced 2 days after she 
emerges this would shorten the time taken to produce a mated queen by four days. Productivity may also benefit from greater timing flexibility when mating nucleus hives are used to rear one queen after another. For example, if the mating of one batch of queens is delayed by bad weather the next batch can be introduced as caged queens rather than as cells.

The aim of this study was to compare three alternative methods of introducing virgin queens into mating nucleus hives in comparison to the usual method of using a ripe queen cell. The results show that introducing oneday-old virgin queens is as successful as using queen cells, and that four-day-old virgins are almost as successful.

\section{MATERIALS AND METHODS}

The study was carried out in a mating apiary in the Bullock Field, Losehill Hall, Castleton, Hope Valley, Derbyshire, England (in the Peak District National Park, Ordinance Survey grid reference 154835). The honey bees here are a mixture of European subspecies, but predominantly A. mellifera mellifera. The mating hives were mating nuclei each with 5 medium-depth Langstroth frames (volume c. $15 \mathrm{~L}$ ) and had sufficient bees to cover 2-4 frames. They were fed sucrose syrup as needed from a feeder in the lid.

Ripe queen cells were obtained using the Doolittle method. Ten or 11 days after grafting the larvae, the control-method group (Cell10-Q) were placed directly into queenless mating nucleus hives, one per hive, by pushing the plastic queen-cell base gently into the comb immediately adjacent to an area with brood. The other queen cells were placed individually into cylindrical $3 \mathrm{~mm}$ wire mesh cages, c. $2.3 \mathrm{~cm}$ diameter $\times 7 \mathrm{~cm}$ long. These cages were then pressed into a frame of honey which was sandwiched between frames of brood in the upper box of a populous hive which was being fed with sugar syrup. The colony queen was confined to the lower box using a queen excluder. The cages were inspected daily for newly-emerged queens.

Each newly-emerged queen was marked with a numbered disc (Opalithplättchen) and put into a wooden three-hole queen-mailing cage containing queen candy (moist paste made of icing sugar and water) in one of the holes. To prevent the caged bees from desiccating or the candy becoming too hard to eat, a drop of water was placed on the candy each day in method Virgin4-Q. In addition, when queens were introduced into a mating nucleus hive, a piece of wax with honey was smeared onto the mesh of the cage to give the queen and attendant bees honey to eat.

Three methods for introducing the virgin queens were used: (1) Virgin1-Q: a caged virgin, 0-24 h old with 6-7 worker bee attendants, released from her cage $3 \mathrm{~d}$ after introduction; (2) Virgin4-Q: as in Virgin1-Q except that the caged queen was held indoors for 3 days at room temperature, c. $20^{\circ} \mathrm{C}$, before introduction; (3) Virgin1+Q: as for Virgin1-Q except that the queen was introduced into a queenright mating hive. Three days after introduction the colony queen was removed and the virgin queen was released after three further days. The rationale of this method was potentially to increase productivity by allowing the current queen longer to lay eggs. In the Virgin1+Q method, half of the mesh of the queen cage was covered with a strip of cardboard to protect the virgin queen from attack by the workers in the mating hive.

In all three methods the virgin queen was released from her cage by removing the cork from the non-candy end of the cage, and temporarily blocking the hole with a piece of wax-honey paste. The worker bees in the mating hive removed this within a few hours. The next day we checked to determine whether the queen had been accepted. Queens alive and uninjured on the combs were considered accepted. Queens found dead inside the cage, being "balled", with injured legs, or which were not found on the next day were considered rejected. A cell was considered accepted if the tip had a round hole indicating successful queen emergence and that the virgin queen was found alive and without wing deformation. A queen cell was considered rejected if the cell had a hole in the side or if the cell was later found intact with a dead queen inside. Starting three days after queen release the mating hives were checked daily for eggs in order to determine the day on which egg laying began.

Queens were introduced in three trials, two in summer 2003 (July-August, August-September, $\mathrm{N}=12$ per method) and one in summer 2004 (JuneJuly, $\mathrm{N}=16$ per method). Method Virgin1+Q was not repeated on the third trial because by this time it was clear that it was inferior and therefore unacceptable for commercial queen rearing. As a result only 24 queens were introduced by this method, versus 40 for the other three methods. 
Table I. Number of virgin queens and queen cells introduced into mating nucleus hives which were accepted or mated in each treatment. The $4 \times 2$ Chi-square test results in the left column indicate whether there is a significant difference among the methods. If there is, additional $2 \times 2$ tests compare particular methods of introducing virgin versus the cell method.

\begin{tabular}{|c|c|c|c|c|}
\hline & \multicolumn{4}{|c|}{ Introduction method } \\
\hline & Cell10-Q & Virgin1-Q & Virgin4-Q & Virgin 1+Q \\
\hline $\begin{array}{c}\text { Introduced, } \mathrm{n} \\
\text { Accepted, } \mathrm{n}(\%) \\
\chi^{2}=7.96, P=0.046\end{array}$ & $\begin{array}{c}40 \\
28(70 \%)\end{array}$ & $\begin{array}{c}\text { Introc } \\
40 \\
30(75 \%) \\
\chi^{2}=0.25, P=0.62\end{array}$ & $\begin{array}{c}c \text { ction-Acceptance } \\
40 \\
26(65 \%) \\
\chi^{2}=0.23, P=0.63\end{array}$ & $\begin{array}{c}24 \\
10(42 \%) \\
\chi^{2}=4.99, P=0.02\end{array}$ \\
\hline $\begin{array}{c}\text { Accepted, } \mathrm{n} \\
\text { Mated, } \mathrm{n}(\%) \\
\chi^{2}=7.37, P=0.06\end{array}$ & $\begin{array}{c}28 \\
28(100 \%)\end{array}$ & $\begin{array}{c}30 \\
26(87 \%)\end{array}$ & $\begin{array}{c}\text { ptance-Laying } \\
26 \\
22(85 \%)\end{array}$ & $\begin{array}{c}10 \\
7(70 \%)\end{array}$ \\
\hline $\begin{array}{c}\text { Introduced, } \mathrm{n} \\
\text { Mated, } \mathrm{n}(\%) \\
\chi^{2}=11.47, P=0.01\end{array}$ & $\begin{array}{c}40 \\
28(70 \%)\end{array}$ & $\begin{array}{c}40 \\
26(65 \%) \\
\chi^{2}=0.22, P=0.63\end{array}$ & $\begin{array}{c}\text { duction-Laying } \\
40 \\
22(55 \%) \\
\chi^{2}=4.18, P=0.04\end{array}$ & $\begin{array}{c}24 \\
7(29 \%) \\
\chi^{2}=10.1, P=0.001\end{array}$ \\
\hline
\end{tabular}

Table II. Age of queen in days on starting to lay eggs in the four introduction methods and three introduction periods.

\begin{tabular}{lccc}
\hline & \multicolumn{3}{c}{ Introduction Period } \\
\cline { 2 - 4 } Introduction method & July-August 2003 & August-September 2003 & June-July 2004 \\
\hline Cell10-Q & $10.0^{\mathrm{a}}$ & $18.4^{\mathrm{b}}$ & $9.7^{\mathrm{c}}$ \\
Virgin1-Q & $10.3^{\mathrm{a}}$ & $19.0^{\mathrm{b}}$ & $9.8^{\mathrm{c}}$ \\
Virgin4-Q & $10.7^{\mathrm{a}}$ & $19.0^{\mathrm{b}}$ & $10.7^{\mathrm{c}}$ \\
Virgin1+Q & $11.3^{\mathrm{a}}$ & $19.0^{\mathrm{b}}$ & \\
\hline All & $10.4^{*}$ & $18.8^{\mathrm{a}}$ & $10.0^{*}$ \\
\hline
\end{tabular}

${ }^{*}$ Means differ significantly $(P<0.01) ;{ }^{\text {a b b c }}$ Means of the same letter do not differ significantly $(P>0.05)$.

A $4 \times 2$ Chi-square test was used to compare the numbers of virgin queens accepted or mated among all methods. When this test found a significant difference we used further $2 \times 2$ Chi-square tests to investigate differences between the cell method and each virgin method. Analysis of variance was used to compare the time taken from emergence to egg laying.

\section{RESULTS}

Table I shows that the proportions of introductions that resulted in a laying queen were 70\% (Cell10-Q), 65\% (Virgin1-Q), 55\% (Virgin4-Q), and 29\% (Virgin1+Q). These proportions differed significantly $\left(\chi^{2} P=\right.$ $0.01)$. Because we were primarily interested in comparing each of the three virgin-queen introduction methods with the usual method, queen cells, we made three post hoc $\chi^{2} 2 \times 2$ tests. There was no significant difference between Cell10-Q and Virgin1-Q $(P=0.63)$. However, Virgin4-Q and Virgin $1+\mathrm{Q}$ were significantly lower $(P=0.04, P=0.001$, respectively).

The proportions of accepted queens that resulted in mated queens were $100 \%, 87 \%, 85 \%$, and $70 \%$ for methods Cell10-Q, Virgin1Q, Virgin4-Q and Virgin1+Q, respectively (Tab. I). There differences were not significant $\left(\chi^{2} P=0.63\right)$.

Table II shows that the average time to begin egg laying was 12.9 days, and was very similar among methods $(P>0.05)$. However, the time taken varied considerably among the three trial periods, due to differences in the weather, with means of $10.4,18.8,10.0$ days 
(July-August 2003, August-September 2003, June-July 2004, respectively).

\section{DISCUSSION}

The results show clearly that introducing virgin queens can be a suitable method in commercial queen rearing in terms of success and egg laying delay. In particular, the overall success rate $(65 \%)$ of one-day-old caged queens was similar to cells $(70 \%)$. When virgin queens were four days old the success rate was still high (55\%), but significantly lower.

There was no significant difference in the time taken to start egg laying, indicating that the time spent in the cage did not interfere with the time schedule of mating and egg-laying. Although the queens from cells started laying slightly sooner than those from cages, the difference was only about half a day which was not significant statistically or of practical importance.

The results also show clearly that initial introduction of a caged virgin into a hive with a mated queen (Virgin1+Q method) is unsuitable given the low overall success, $29 \%$. The presence of the mated queen during the introduction period caused the workers in the mating hive to behave aggressively towards the introduced virgin queen (Szabo, 1977). A large proportion $(21 \%)$ of the Virgin 1+Q queens died inside their cages due to the attacks of the workers and $50 \%$ of those that survived in their cages were rejected after being released.

Overall, most queen loss occurred in the introduction (caged queen) or cell emergence period, with only one third in the mating period. A considerable proportion of the queen cells introduced was found intact with a dead queen or pupa inside $(11 \%)$ or destroyed (19\%). However, all the queens that emerged from cells mated successfully. This suggests that greater success in queen rearing could be obtained by improving the acceptance of young queens, both caged virgins and cells.

The high mating success in this study may be because the mating hives were deliberately set up to make it easy for queens to return to their own hive. The hives were in pairs on each hive stand (a car tyre) with entrances fac- ing in opposite directions, and had their entrances painted different colours to facilitate orientation. In addition, the hives were relatively widely spaced, c. $5 \mathrm{~m}$, between hive stands, which were all in a line c. $2 \mathrm{~m}$ from the hedge bordering the western boundary of the field. Nevertheless, this is still much closer than colonies of A. mellifera normally occur in nature and it is possible that some of virgin queen returned to the wrong hive after mating (Ratnieks, 1990).

The mortality rate during the mating period for the 94 queens that were accepted in all four treatments was $12 \%$ which is lower than the $19.5 \%$ obtained by Medina and Gonçalves (2001). Other studies show even lower mortality rates. For example, $4 \%$ mortality during the mating period for $A$. m. ligustica queens in New York using mating nucleus hives located singly, with wide spacing (c. $5 \mathrm{~m}$ ) and in an old field with many small bushes to provide orientation landmarks (Ratnieks, 1990) and $0 \%$ in A. mellifera in South Africa (Fletcher, 1978). However, our $12 \%$ loss during the mating period might be an overestimate of mating losses. All queens that emerged from cells mated successfully. When caged virgins were introduced, the mating hive was checked one day after the queen had been released from her cage. Undamaged queens on the combs were considered accepted. However, it is possible that some of these accepted queens were rejected later. If this were the case then some mortality during the mating period is actually acceptance mortality, not mating mortality.

Our results suggest certain recommendations to increase queen rearing success. When cells are used, it may be advantageous to "candle" queen cells and to discard any which are suspected to have a dead pupa. The problem of cells not emerging can be minimised by careful handling of cells, and also by providing two cells per mating hive. Given that $11 \%$ of the cells failed to emerge this would result in a useful gain in overall success, but at the cost of needing twice as many ripe queen cells. When virgin queens are used, our results indicate that the younger they are the better, but that virgins 3-4 days old are only slightly less successful than virgins $0-1$ days old. This suggests that virgins can be sent through the mail provided 
that they are sent on the day of emergence, that the mail is swift (one or two days), and that they are immediately placed into queen mating hives on arrival. Our results also show that the design of our mating apiary, with hives located in pairs every $5 \mathrm{~m}$ in a line along the edge of a field, is not only practical but gives very low mating losses. Overall, loss of queens during the mating period was less important than during queen introduction and acceptance.

\section{ACKNOWLEDGEMENTS}

We thank CONACyT for a Ph.D. studentship to AP-S and to Losehill Hall for providing the apiary site. In addition, we would like to thanks two anonymous referees for their useful comments.

Résumé - Comparaison de méthodes d'introduction de reines vierges d'abeilles (Apis mellifera) dans des nuclei de fécondation. Le but de cette étude est de comparer 3 méthodes d'introduction de reines vierges dans des nuclei de fécondation avec la méthode habituelle, considérée comme plus efficace, qui utilise une cellule royale mûre. L'introduction de reines vierges présente divers avantages potentiels : (i) les reines peuvent être marquées à la peinture ou recevoir des étiquettes numérotées, utiles pour les retrouver facilement; (ii) les reines peuvent être sélectionnées en fonction de caractères physiques souhaités (couleur, absence de déformation, taille corporelle adéquate, etc.). Finalement la productivité de l'élevage de reines peut être augmentée. Les cellules royales sont habituellement introduites $2 \mathrm{j}$ avant l'émergence de la reine. Si une reine vierge est introduite $2 \mathrm{j}$ après son émergence, cela réduit de $4 \mathrm{j}$ le délai pour produire une reine fécondée. La productivité peut aussi bénéficier d'une plus grande flexibilité quand les nuclei de fécondation sont utilisés pour élever des reines les unes après les autres. Par exemple, si la fécondation d'un groupe de reines est retardée par le mauvais temps, le groupe suivant peut être introduit sous forme de reines encagées plutôt que de cellules.

Les 3 méthodes comparées sont : (1) reine vierge d' $1 \mathrm{j}$ introduite à l'aide d'une cage à reines en bois à 3 trous dans un nucleus orphelin comportant 5 cadres Langstroth et 5-7 ouvrières accompagnatrices; (2) comme (1) mais la reine encagée a 4 j à l'introduction et a été maintenue les $3 \mathrm{j}$ précédents dans sa cage à température ambiante; (3) comme (1) mais le nucleus n'est pas orphelin. Trois $j$ après l'introduction de la reine vierge encagée, la reine pondeuse est enlevée et la reine vierge libérée $3 \mathrm{j}$ plus tard ; (4) une cellule «mûre », $10 \mathrm{j}$ après le greffage de la jeune larve, est introduite dans un nucleus orphelin.
Les résultats montrent clairement que l'introduction de reines vierges d' $1 \mathrm{j}$ dans des nuclei orphelins (méthode 1) est presque aussi efficace $(65 \%)$ que l'utilisation de cellules royales $(70 \%)$ pour obtenir une reine pondeuse. La méthode 2 n'est que légèrement moins efficace $(55 \%)$. La méthode 3 ne convient pas avec seulement $29 \%$ de réussite : une grande proportion de cellules royales introduites ont été trouvées intactes avec une nymphe morte $(11 \%)$ ou détruite $(19 \%)$. Pourtant toutes les reines qui ont émergé des cellules introduites se sont accouplées avec succès. Cela suggère qu'un plus grand succès dans l'élevage de reines pourrait être obtenu en augmentant l'acceptation des jeunes reines, que ce soit des reines vierges encagées ou des cellules introduites. Le délai pour le début de la ponte a été d'environ $12,9 \mathrm{j}$ et très semblable quelle que soit la méthode. Ceci indique que le temps passé dans la cage n'a pas interféré avec les dates d'accouplement et de début de ponte. Les éleveurs de reines peuvent donc s'attendre à des taux de réussite comparables à celui des cellules s'ils utilisent des reines vierges d'1 j ou plusieurs j encagées.

Apis mellifera / reine vierge / acceptation des reines / introduction de reines / élevage de reines / succès d'accouplement

Zusammenfassung - Vergleich alternativer Methoden für das Zusetzen von unbegatteten Königinnen (Apis mellifera) in Begattungskästchen. Der Erfolg von 3 verschiedenen Zusetzmethoden von unbegatteten Königinnen wurde mit dem Einsetzen von reifen Weiselzellen verglichen. Oft wird angenommen, dass das Zusetzen von Jungköniginnen verlustreicher ist als die Einführung von Weiselzellen. Der Zusatz von Jungköniginnen hat aber einige Vorteile: 1 . Königinnen können vor dem Zusetzen markiert werden. 2. Äußere Eigenschaften der Königinnen können überprüft werden (Farbe, Größe, Missbildungen etc.). 3. Die Produktion von Königinnen kann erhöht werden. Weiselzellen werden meist 2 Tage vor dem Schlupf ins Volk eingeführt. Bei Einsatz von Königinnen 2 Tage nach dem Schlupf spart man 4 Tage im Begattungskästchen bis zur Paarung. Die Produktivität könnte außerdem durch die größere zeitliche Flexibilität profitieren, wenn die Begattungskästchen mehrmals hintereinander benutzt werden. Z.B. könnte man bei Verzögerungen durch schlechte Wetterbedingungen bereits die nächsten Königinnen im Käfig ,parken“

Folgende Methoden wurden verglichen: (1) Virgin1-Q: Eine 1 Tag alte Königin wurde in ein weiselloses Begattungskästchen mit 5 Langstroth Rahmen in einem Versandkäfig mit 3 Kammern und 5-7 Bienen eingesetzt und 3 Tage später freigesetzt. (2) Virgin4-Q: Wie (1), aber die Königin war beim Zusetzen bereits 4 Tage alt und war 3 Tage bei Zimmertemperatur im Käfig 
gehalten worden. (3) Virgin1+Q: Wie (1) aber das Begattungskästchen hatte eine Königin. Die begattete Königin wurde erst 3 Tage nach der Einführung entfernt und die Jungkönigin erst nach 3 weiteren Tagen freigegeben. (4) Cell10-Q: Eine „reife“ Weiselzelle (10 Tage nach dem Umlarven) wurde in ein weiselloses Begattungskästchen eingeführt.

Die Zahl von Königinnen in Eilage war nach Zusetzen von 1 Tag alten Königinnen in weisellose Begattungskästchen mit $65 \%$ fast genauso gut wie nach Einsetzung von Weiselzellen (70 \%). Die Virgin4-Q Methode war nur wenig schlechter (55\%). Die Virgin1+Q Methode ist mit nur $29 \%$ eierlegender Königinnen ungeeignet. Bei einem beachtlichen Prozentsatz (11\%) der eingebrachten Weiselzellen wurden tote Puppen gefunden oder sie waren zerstört (19\%). Allerdings war die Paarung von allen aus Zellen geschlüpften Königinnen erfolgreich. Demnach würde ein größerer Erfolg bei der Königinnenzucht erreicht werden, wenn die Annahme von zugesetzten Königinnen bzw Weiselzellen verbessert würde. Die Zeitspanne bis zum Beginn der Eilage war im Mittel 12.9 Tage und war bei allen Methoden statistisch nicht zu unterscheiden. Das zeigt, dass die Zeit im Käfig keinen Einfluss auf den Zeitablauf für Paarung und Beginn der Eilage hat. Nach diesen Ergebnissen können Königinnenzüchter beim Einweiseln von wenige Tage alten Königinnen ähnliche Erfolgsquoten erreichen wie bei dem Zusetzen von Weiselzellen.

\section{Apis mellifera / unbegattete Königinnen / Kö- niginnenannahme / Einweiselung / Weiselzelle / Paarungserfolg}

\section{REFERENCES}

Châline N., Ratnieks F.L.W., Raine N.E., Badcock N.S., Burke T. (2004) Non-lethal sampling of honey bee, Apis mellifera, DNA using wing tips, Apidologie 35, 311-318.

Fletcher D.J.C. (1978) The African bee, Apis mellifera adansonii, in Africa, Annu. Rev. Entomol. 23, 151-171.

Laidlaw H.H. (1979) Contemporary queen rearing, Dadant and Sons, Hamilton, Illinois.

Laidlaw H.H. (1993) Production of queens and package bees, in: Graham J.M. (Ed.), The hive and the honey bee, Dadant and Sons, Hamilton, Illinois, pp. 989-1042.

Laidlaw H.H., Page R.E. (1997) Queen rearing and bee breeding, Wicwas Press, Cheshire, Connecticut.

McCutcheon D. (2001) Queen introduction, Bee World $82,5-21$.

Medina L.M., Gonçalves L.S. (2001) Effect of weight at emergence of africanized (Apis mellifera L.) virgin queens on their acceptance and beginning of oviposition, Am. Bee J. 213-215.

Ratnieks F.L.W. (1990) The evolution of polyandry by highly eusocial bee queens: The importance of progressive versus mass provisioning and the timing of removal of diploid males, Behav. Ecol. Sociobiol. 26, 342-348.

Ruttner F. (1983) Queen rearing: biological basis and technical instructions. Apimondia Publishing House, Bucharest, Romania.

Snelgrove L.E. (1940) The introduction of queen bees. Purnell and Sons, London, UK.

Szabo T.I. (1977) Behavioural studies of queen introduction in the honey bee. VI. Multiple queen introduction, J. Apic. Res. 16, 65-83. 